\title{
DEVELOPMENT CREATIVITY STUDENTS THROUGH THE APPLICATION OF PROBLEM BASED LEARNING MODEL IN PHYSICAL EDUCATION IN REVIEWED OF ADVERSITY QUOTIENT
}

\author{
Edi Setiawan ${ }^{1 *}$, Tite Juliantine ${ }^{2}$, Komarudin ${ }^{3}$ \\ ${ }^{1}$ Universitas Pendidikan Indonesia, \\ email : edisetiawan@student.upi.edu
}

\begin{abstract}
Abstrak
The purpose of this research is to develop students' creativity through the application of problem based learning model in physical education in review of adversity quotient. The research method used is experimental method with $2 \times 2$ factorial designs. The population in this study are the students of 10th grade in SMK 1 Cipanas Cianjur Regency consists of 10th grade as many as 8 classes with a total of 375 students. The sample in this research is as many as 60 students, consists of 30 students with high adversity quotient skills and 30 students with low adversity quotient skills. The sampling using cluster random sampling technique. The instrument used is a questionnaire to measure the level of adversity quotient by Stolz (2000) and the creativity by Guilford (1950). The result of data analysis Two Way Anova showed that: (1) the development of students' creativity through problem based learning model is higher than direct instruction model. (2) There are differences of creativity between students who are given problem-based learning model and direct instruction model in groups of students who have high adversity quotient ability.(3)There are differences of creativity between students who are given problem-based learning model and direct instruction model in groups of students' who have low adversity quotient ability. (4) There are interactions between the learning model and the adversity quotient on students' creativity. The findings of this study confirmed that learning with problem based learning model gives more effective impact and can be applied by physical education teachers in an effort to develop student' creativity.
\end{abstract}

Key word: Learning Model, Problem Based Learning, Direct Instruction, Adversity

Quotient \& Creativity Development

\section{INTRODUCTION}

In this globalization era, creativity is an important element in development and it is a basic capital in building a better quality of human resources in a country (Bereczki, 2016; Cheung, 2016). The term creativity is very difficult to define because creativity is a multidimensional concept so that many experts are advocating the meaning of creativity (Turpin, Matthee, \& Kruger, 2015). The difference in the definition of creativity put forward by experts is a complementary definition, But the term that is often used in the world of education that creativity can be interpreted as a person's ability to create something new both in concepts or real work (Cheung, 2016; Rasmussen \& Østergaard, 2016).

Creativity is the result of the process of interaction between individuals and their environment. A person can be influenced by the environment in which he is located. It means, the creativity that is owned by a person can develop depending on the environment he is in. Student creativity can grow and develop well, if family environment, society, especially school environment also support them in expressing their creativity (Zimmerman, 2009). Related to the explanation, then one of the efforts to bridge the development of student creativity is through learning physical education in the school 
environment (Cheung, 2010). But unfortunately, research on creativity is still rarely done in the world of education, especially physical education (Konstantinidou, Michalopoulou, Agelousis, \& Kourtesis, 2013). There is a learning model that is expected to be able to increase the creativity that is owned by students is by applying problem based learning model. Because problem based learning is a learning model, where physical education teachers provide a problem and give students the freedom to learn to solve problems and find solutions to the problem independently (Bethell \& Morgan, 2011). Thus, it can be concluded that in addition to external factors that is by applying the model of problem based learning into learning physical education is able to facilitate students to improve their creativity (Awang \& Ramly, 2008; Folly Eldy \& Sulaiman, 2013). Nevertheless it cannot be denied that the quality of adversity quotient students themselves in the face of a problem is an internal factor is crucial to the development of a creativity.

The role of adversity quotient in physical education is to help students not to give up easily and not easily despair of the learning problems they face. Adversity quotient can be interpreted as the intelligence of a person in the face of difficulties or problems and help students to increase the potential within him that includes various components such as performance, motivation, empowerment, creativity, productivity (Parvathy \& Praseeda, 2014). The better the adversity quotient the student has, the higher the creativity or the better the student is able to give a good response and able to survive in overcoming a difficulty, the higher the spirit of creation (Zhi-hsien, 2014).

According to the problems that have been described above, the purpose of this research is to develop students' creativity through the application of problem based learning model in physical education in review of adversity quotient. Based on the analysis of previous research showed no one ever to study and try to apply problem based learning model and adversity quotient in an effort to develop students' creativity in physical education. This study confirm that learning with problem based learning model is more effective impact and can be applied by physical education teachers in an effort to develop student creativity.

\section{METHOD}

\section{Participants}

This research will be conducted at SMK 1 Cipanas Cianjur. The population used was $10^{\text {th }}$ grade student at SMK 1 Cipanas, Cianjur Regency in the academic year of 2016-2017 consisting of $10^{\text {th }}$ grade of 8 classes with details: X TPHP 1 and 2, X TN 1 and 2, X TKJ 1 and 2, X TKR 1 and 2, the total sample are 375 students. Its using cluster random sampling technique. The sample in this study were 60 students, consisting of 30 students who have high AQ and 30 students who have low AQ.

\section{Procedures}

The research method used is experimental method with $2 \times 2$ factorial designs. The study was conducted for 5 weeks, while the learning was done 14 times as a whole, With details for the treatment of 12 meetings and 2 times that is one to perform the pretest and one to perform the posttest, with frequency 3 times a week, the treatment was given to the experimental group using problem based learning model, while in the control group using direct instruction model.

The instrument used is a questionnaire to measure the level of adversity quotient theory proposed by Stolz (2000) and the theoretical creativity put forward by Guilford (1950). This instrument is not known with certainty to have the validity and reliability of how much, therefore the authors will reexamine this instrument to find validity and reliability upon high school students of class X TKJ and $\mathrm{X}$ TKR in SMK 1 Cipanas Cianjur.I 


\section{RESULTS dan DISCUSSION}

\section{Descriptive Statistic Learning Model with High and Low AQ}

Table 1. Descriptive Statistics Learning Model with High Adversity Quotient

\begin{tabular}{cccccc}
\hline Model Type & Type of Test & Mean & $\begin{array}{c}\text { Std. } \\
\text { Deviation }\end{array}$ & Minimum & Maximum \\
\hline Learning model & Pretest & 136.07 & 20.954 & 106 & 165 \\
PBL & Posttest & 139.80 & 20.892 & 109 & 170 \\
Learning model & Pretest & 129.00 & 19.567 & 100 & 160 \\
DI & Posttest & 139.67 & 20.725 & 120 & 190 \\
\hline
\end{tabular}

Based on the analysis of descriptive statistics with the help of SPSS version 17.0, on the learning model with high AQ data obtained from the results of pretest group problem based learning model, the mean value is $=136.07$, std. deviation $=20.954$, minimum value is $=106$ and maximum value is $=165$, Then for post test result in group problem learning model, the mean value is $=139.80$, std. deviation $=20.892$, minimum value is $=109$ and maximum value is $=170$. While the results of the pretest group of direct instruction model, the mean value is $=129.00$, std. deviation $=19.567$, minimum value is $=100$ and maximum value is $=160$. Then for posttest result in group of direct instruction model, the mean value is $=139.67$, std. deviation $=20.725$, minimum value $=120$ and maximum value $=190$.

Table 2. Descriptive Statistics Learning Model with Low Adversity Quotient

\begin{tabular}{cccccc}
\hline Model Type & Jenis Tes & Mean & $\begin{array}{c}\text { Std. } \\
\text { Deviation }\end{array}$ & Minimum & Maximum \\
\hline Learning model & Pretest & 131.53 & 19.026 & 106 & 157 \\
PBL & Posttest & 136.13 & 19.932 & 108 & 160 \\
Learning model & Pretest & 136.47 & 22.293 & 100 & 170 \\
DI & Posttest & 141.53 & 21.970 & 110 & 175 \\
\hline
\end{tabular}

Based on the analysis of descriptive statistics with the help of SPSS version 17.0, on the learning model with low AQ data obtained from the results of pretest group problem based learning model, the mean value is $=131.53$, std. deviation $=19.026$, minimum value is $=106$ and maximum value is $=157$, Then for posttest result in group problem learning model, the mean value is $=136.13$, std. deviation $=19.932$, minimum value is $=108$ and maximum value is $=160$. While the results of the pretest group of direct instruction model, the mean value is $=136.47$, std. deviation $=22.293$, minimum value is $=100$ and maximum value is $=170$. Then for posttest result in group of direct instruction model, the mean value is $=141.53$, std. deviation $=21.970$, minimum value $=110$ and maximum value $=175$. 
Tabel 3. Results of the First Hypothesis Calculation with Two-Way Anova

\begin{tabular}{lccc}
\hline No & Variable Name & Sig (2-tailed) & $\boldsymbol{\alpha}$ \\
\hline 1. & $\begin{array}{c}\text { Learning model } \\
\text { PBL with DI }\end{array}$ & 0.004 & 0.05 \\
\hline
\end{tabular}

Based on table 9 it is known that the Sig (2-tailed) value is 0.004 , since the Sig (2-tailed) value is $0.004<\alpha 0.05$, then Ho is rejected. This means that there is a difference of creativity between students who are given learning model problem based learning and students who are given direct instruction model.

Tabel 4. Results of the second Hypothesis Calculation with Two-Way Anova

\begin{tabular}{lccc}
\hline No & Variable Name & Sig (2-tailed) & $\boldsymbol{\alpha}$ \\
\hline 1. & Learning Model with High Adversity Quotient & 0.000 & 0.05 \\
\hline
\end{tabular}

Based on table 10 it is known that the Sig (2-tailed) value is 0,000 , since the Sig (2-tailed) value is $0.000<\alpha 0.05$, then Ho is rejected. This means that there is a difference of creativity between students who are given learning model problem based learning and direct instruction model in groups of students who have high adversity quotient ability.

Tabel 5. Results of the Thrid Hypothesis Calculation with Two-Way Anova

\begin{tabular}{lccc}
\hline No & Variable Name & Sig (2-tailed) & $\boldsymbol{\alpha}$ \\
\hline 1. & Learning Model with Low Adversity Quotient & 0.000 & 0.05
\end{tabular}

Based on table 11 it is known that the Sig (2-tailed) value is 0,000 , since the Sig (2-tailed) value is $0.000<\alpha 0.05$, then Ho is rejected. This means that there is a difference of creativity between students who are given learning model of problem based learning and direct instruction model in groups of students who have low adversity quotient ability.

Tabel 6. Results of the four Hypothesis Calculation with Two-Way Anova

\begin{tabular}{lccc}
\hline No & Variable Name & Sig (2-tailed) & $\boldsymbol{\alpha}$ \\
\hline 1. & $\begin{array}{c}\text { Interaction between learning model and adversity } \\
\text { quotient on student creativity }\end{array}$ & 0.003 & 0.05 \\
\hline
\end{tabular}

Based on table 12 it is known that the Sig (2-tailed) value is 0.003 , since the Sig (2-tailed) value is $0.003<\alpha 0.05$, then Ho is rejected. This means that there is an interaction between learning model and adversity quotient on student creativity. To be more clear about the interaction between learning model and adversity quotient on students' creativity can be seen in graph form as follows: 


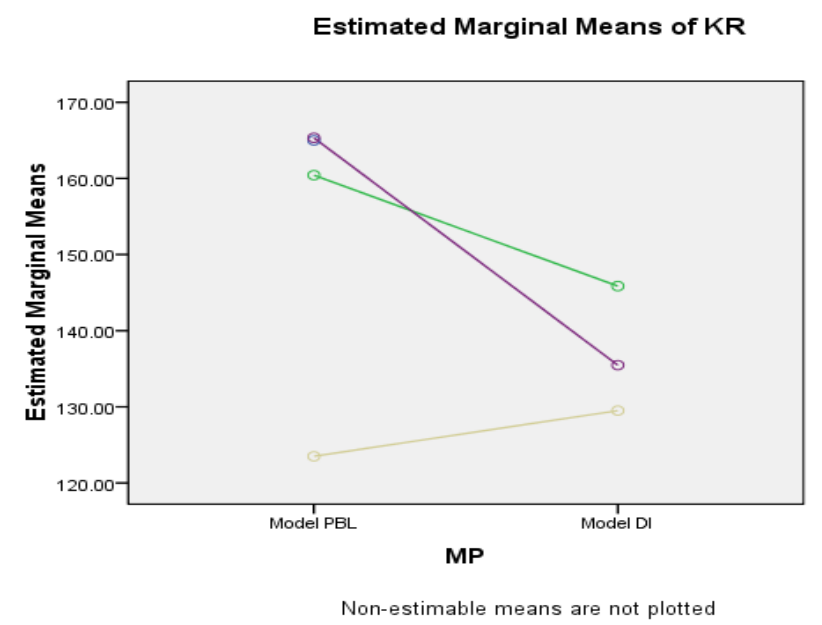

Based on the graphic above, it can be concluded that there is interaction between learning model and adversity quotient toward student creativity.

\section{CONCLUSION}

The findings of this study confirms that learning with problem based learning model has more effective impact and can be applied by physical education teachers in an effort to develop student creativity. Based on the limitations in this study that PBL is not suitable applied to low AQ, for it is expected for researchers who can further complement the existing deficiencies in this study.

\section{DAFTAR PUSTAKA}

Bereczki, E. O. (2016). Mapping creativity in the Hungarian National Core Curriculum: a content analysis of the overall statements of intent, curricular areas and education levels. The Curriculum Journal, 27(3), 330-367. https://doi.org/10.1080/09585176.2015.1100546

Bethell, S., \& Morgan, K. (2011). Problem-based and experiential learning: Engaging students in an undergraduate physical education module. The Journal of Hospitality Leisure Sport and Tourism, 10(1), 128-134. https://doi.org/10.3794/johlste.101.365

Chen, W. (2013). Applying Problem-Based Learning Model and Creative Design to Conic-Sections Teaching, 7(3), 73-80.

Cheung, R. H. P. (2010). Designing movement activities to develop children's creativity in early childhood education. Early Child Development and Care, 180(3), 377-385. https://doi.org/10.1080/03004430801931196

Cheung, R. H. P. (2016). The challenge of developing creativity in a Chinese context: the effectiveness of adapting Western creative pedagogy to inform creative practice. Pedagogy, Culture \& Society, 24(1), 141-160. https://doi.org/10.1080/14681366.2015.1087419

Folly Eldy, E., \& Sulaiman, F. (2013). The Role of PBL in Improving Physics Students' Creative Thinking and Its Imprint on Gender. International Journal of Education and Research, 1(6). 
Guilford, J.P . (1950). Creativity Research . New York: University Press.

Konstantinidou, E., Michalopoulou, M., Agelousis, N., \& Kourtesis, T. (2013). Primary Physical Education Perspective on Creativity: The Characteristics of the Creative Student and Their Creative Outcomes. International Journal of Humanities and Social Science, 3(3), 2015.

Parvathy, U., \& Praseeda, M. (2014). Relationship between Adversity Quotient and Academic Problems among Student Teachers, 19(11), 23-26.

Rasmussen, L. J. T., \& Østergaard, L. D. (2016). The Creative Soccer Platform: New Strategies for Stimulating Creativity in Organized Youth Soccer Practice. Journal of Physical Education, Recreation \& Dance, 87(7), 9-19. https://doi.org/10.1080/07303084.2016.1202799.

Stoltz. (2000). Adversity Quotient Mengubah Hambatan Menjadi Peluang. Grasindo: Jakarta.

Temel, Senar (2014). The effects of problem-based learning on pre-service teachers' critical thinking dispositions and perceptions of problem-solving ability . South African Journal of Education; $2014 ; 34(1)$.

Turpin, M., Matthee, M., \& Kruger, A. (2015). The Teaching of Creativity in Information Systems Programmes at South African Higher Education Institutions. African Journal of Research in Mathematics, Science and Technology Education, 19(3), 278-288. https://doi.org/10.1080/10288457.2015.1104838.

Zhi-hsien, C. V. (2014). A Study Investigating the Influence of Demographic Variables on Adversity Quotient. Journal of Human Resource and Adult Learning, 10(June), 22-32.

Zimmerman, E. (2009). Reconceptualizing the Role of Creativity in Art Education Theory and Practice - ProQuest. Studies in Art Education, 50(4), 382-399. https://doi.org/http://dx.doi.org/10.1080/00393541.2009.11518783. 